\title{
Nytt alvorlig luftveissyndrom
}

Midtøstluftveissyndrom (Middle East respiratory syndrome, MERS) er en ny infeksjonssykdom som gir luftveissymptomer og som kan være dødelig.

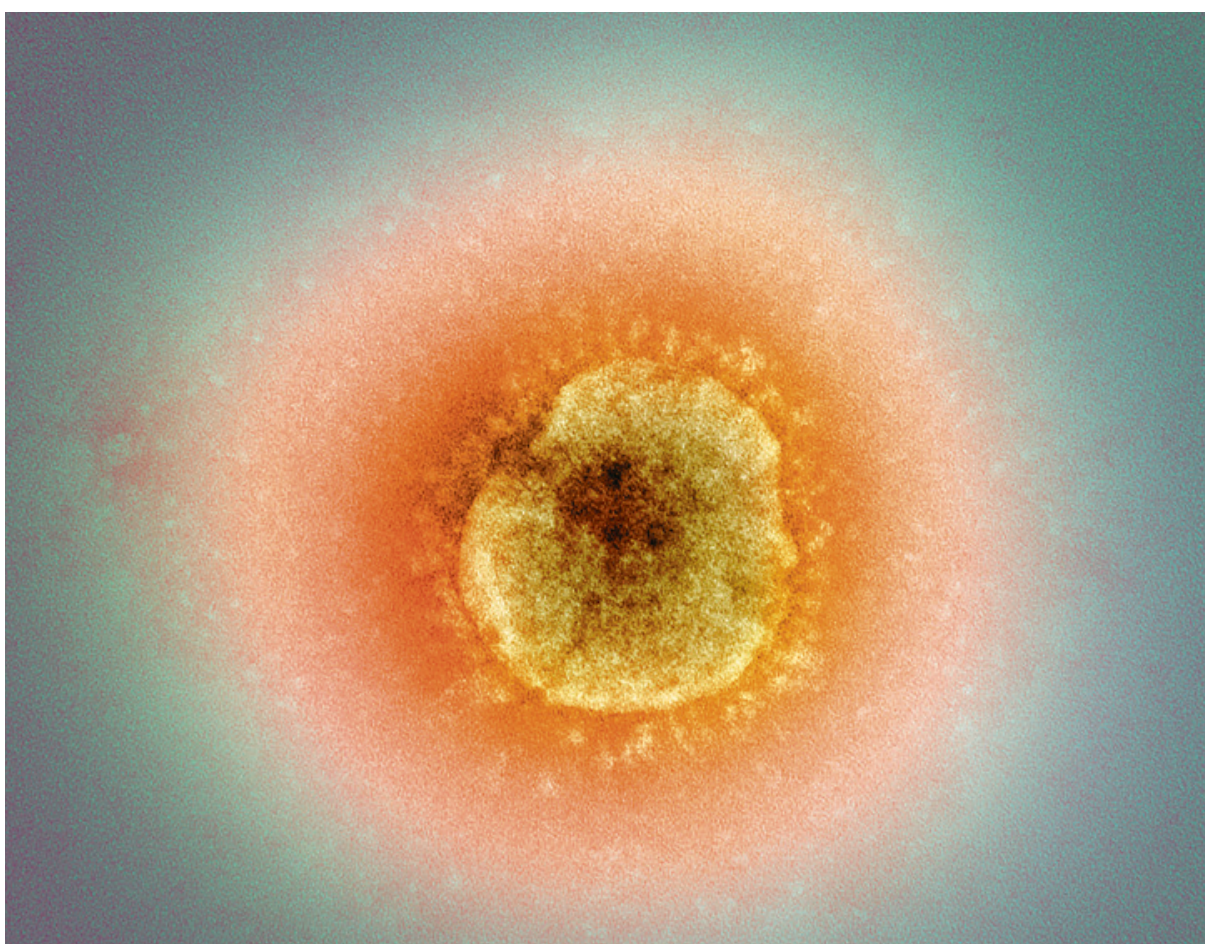

Illustrasjonsfoto Sciencephoto/NTB scanpix

Midtøstluftveissyndrom (Middle East respiratory syndrome, MERS) skyldes et tidligere ukjent coronavirus som ble identifisert i Saudi-Arabia i september 2012. De fleste tilfellene har vært i Saudi-Arabia, men sykdommen er også funnet $i$ andre land i Midtøsten og Europa. Innen 21. juli 2013 var det rapportert om 90 tilfeller globalt, hvorav 45 hadde fatal utgang. Sykdommen er ny og mye er ukjent om den, men kliniske og epidemiologiske karakteristika blir beskrevet i en oppsummering av 47 saudiarabiske tilfeller bekreftet ved polymerasekjedereaksjonstest (1).

Median inkubasjonstid var 5,2 dager. Vanlige symptomer var feber (hos 46), hoste (hos 39), kortpust (hos 34), myalgi (hos 15), diaré (hos 12), oppkast (hos ti) og magesmerter (hos åtte). Det var patologiske funn på røntgen thorax hos samtlige. 42 måtte på intensivavdeling og 34 fikk respiratorbehandling. Ingen hadde funn som tydet på bakteriologiske eller virale koinfeksjoner.

Tre firedeler av pasientene var menn. Alle aldersgrupper var representert, men dødeligheten var stigende med $ø$ kende alder $(13$

\section{Forebyggende behand- ling hos pasienter med diabetes kan bli bedre}

\author{
Fastleger i Groruddalen kan bli \\ enda bedre til å forebygge hjerte- \\ og karsykdom hos pasienter med \\ type 2-diabetes.
}

Vi har nylig publisert en studie om hvordan farmakologisk forebygging av hjerte- og karsykdom gjennomføres hos pasienter med type 2-diabetes og ulik etnisk bakgrunn i flere bydeler i Oslo. Studien omfattet flere enn 1600 pasienter hos 49 fastleger i Groruddalen.

Blant pasienter uten kardiovaskulær sykdom var det noen pasienter som burde fått farmakologisk forebyggende behandling, men som ikke fikk det. Dette gjaldt $1,5 \%$ av dem med for høyt HbA1c-nivå, $4,8 \%$ av dem med forhøyet systolisk blodtrykk og $12,7 \%$ av dem med lipidverdier over terapeutisk grense. Blant pasientene som fikk blodsukkersenkende behandling, var det $34 \%$ som ikke nådde behandlingsmålet på HbA1c $\leq 7,5 \%: 26 \%$ blant etnisk norske, $38 \%$ blant dem med sørasiatisk bakgrunn og $29 \%$ blant dem fra andre regioner. Av dem som fikk blodtrykksbehandling, var det $38 \%$ som ikke nådde behandlingsmålet (systolisk blodtrykk $\leq 140 \mathrm{~mm} \mathrm{Hg}$ ): $42 \%$ hos etnisk norske, $22 \%$ hos sørasiater og $25 \%$ hos andre grupper. Behandlingsmålet for dyslipidemi (totalkolesterol/HDL-kolesterol $<4$ ) ble oppnådd hos $62 \%$.

Av 380 pasienter med kjent hjerte- og karsykdom fikk de fleste sekundær farmakologisk profylaktisk behandling. Rundt $65 \%$ av dem som fikk behandling, nådde behandlingsmålene.

Studien viser at fastleger i Groruddalen i stor grad følger nasjonale anbefalinger for oppstart av farmakologisk forebyggende behandling av hjerte- og karsykdom hos pasienter med type 2-diabetes. Lipidsenkende behandling ble brukt for lite. Måloppnåelse for blodsukkersenkende behandling hos pasienter med minoritetsbakgrunn og for blodtrykksbehandling hos etnisk norske kan bli bedre.

\section{kristoffer.brodwall@gmail.com}

Institutt for Global helse og samfunnsmedisin Universitetet i Bergen

\section{Litteratur}

1. Assiri A, Al-Tawfiq JA, Al-Rabeeah AA et al. Epidemiological, demographic, and clinical characteristics of 47 cases of Middle East respiratory syndrome coronavirus disease from Saudi Arabia: a descriptive study. Lancet Infect Dis 2013; 13 . 752-61.

\section{Anh Thi Tran}

a.t.tran@medisin.uio.no

Universitetet i Oslo

\section{Litteratur}

1. Tran AT Straand J, Dalen I et al. Pharmacological primary and secondary cardiovascular prevention among diabetic patients in a multiethnic general practice population: still room for improvements. BMC Health Serv Res 2013; 13: 182. 